\title{
Preliminary study of regionalised centre-of- pressure analysis in patients with juvenile idiopathic arthritis
}

Gordon J Hendry ${ }^{1,2^{*}}$, Danny Rafferty ${ }^{1}$, Ruth Semple, Janet M Gardner-Medwin ${ }^{3}$, Debbie E Turner ${ }^{1}$, James Woodburn ${ }^{1}$

From 3rd Congress of the International Foot and Ankle Biomechanics Community Sydney, Australia. 11-13 April 2012

\section{Background}

Patients with Juvenile idiopathic arthritis (JIA) may exhibit altered plantar pressure distributions as a result of foot pain and/or deformities [1,2]. Previous work involving adult patients with rheumatoid arthritis suggests that altered loading patterns can be characterised by delayed transfer of the centre-of-pressure to the forefoot [3]. The aim of this study was to compare centre-of- pressure characteristics in pre-defined areas of the foot between patients with JIA and children without JIA.

\section{Methods}

Fourteen patients with JIA (10 female, 4 male) with a mean age of 12.4 years (SD 3.2), and 10 controls (6 female, 4 male) with a mean age of 12.5 years (SD 3.4) were studied. Foot deformity and impairment scores

Table 1 Mean (standard deviation) of the regionalised CoP variables for the JIA and able-bodied control groups.

\begin{tabular}{|c|c|c|c|c|}
\hline Variable & Region & $J \mid A(n=14)$ & Controls $(n=10)$ & Mean difference $(95 \% \mathrm{Cl})$ \\
\hline \multirow[t]{5}{*}{$\operatorname{VCoP}_{\text {ave }}(\mathrm{m} / \mathrm{s})$} & Foot & $0.28(0.03)$ & $0.31(0.05)$ & $0.02(0.00,0.05)$ \\
\hline & Heel & $0.27(0.08)$ & $0.29(0.10)$ & $0.02(-0.02,0.08)$ \\
\hline & Midfoot & $0.42(0.10)$ & $0.48(0.08)$ & $0.06(0.00,0.12)$ \\
\hline & Forefoot & $0.22(0.03)$ & $0.23(0.05)$ & $0.01(-0.02,0.03)$ \\
\hline & Toes & $0.76(0.48)$ & $0.69(0.25)$ & $-0.06(-0.40,0.28)$ \\
\hline \multirow[t]{5}{*}{$V_{C o P} \max (m / s)$} & Foot & $1.39(0.77)$ & $1.38(0.60)$ & $-0.01(-0.62,0.60)$ \\
\hline & Heel & $0.59(0.14)$ & $0.65(0.17)$ & $0.06(-0.07,0.19)$ \\
\hline & Midfoot & $0.63(0.32)$ & $0.66(0.09)$ & $0.03(-0.18,0.25)$ \\
\hline & Forefoot & $0.83(0.42)$ & $0.86(0.33)$ & $0.03(-0.29,0.36)$ \\
\hline & Toes & $1.23(0.73)$ & $1.31(0.57)$ & $0.08(-0.49,0.66)$ \\
\hline \multirow[t]{4}{*}{ DCoP (\% stance) } & Heel & $25.83(6.96)$ & $26.01(6.91)$ & $0.18(-5.78,6.14)$ \\
\hline & Midfoot & $20.71(4.14)$ & $19.19(3.63)$ & $-1.52(-4.89,1.87)$ \\
\hline & Forefoot & $46.54(8.92)$ & $48.20(7.51)$ & $1.66(-5.53,8.85)$ \\
\hline & Toes & $6.92(3.27)$ & $6.60(1.22)$ & $-0.32(-2.58,1.94)$ \\
\hline $\operatorname{VCoP}(\mathrm{m} / \mathrm{s})$ & $50 \%$ foot length & $46.54(7.28)$ & $45.21(7.93)$ & $-1.34(-7.82,5.15)$ \\
\hline
\end{tabular}

$\mathrm{VCoP}_{\text {ave }}(\mathrm{m} / \mathrm{s})$ : average velocity of the centre of pressure; $\mathrm{VCoP}_{\max }(\mathrm{m} / \mathrm{s})$ : maximum velocity of the centre of pressure; DCoP (\% stance): duration of the centre of pressure; Cl: confidence interval

\footnotetext{
* Correspondence: gordon.hendry@uws.edu.au

'School of Health and Life Sciences, Glasgow Caledonian University,

Glasgow, Lanarkshire, G4 OBA, UK

Full list of author information is available at the end of the article
}

\section{() Biomed Central}

(c) 2012 Hendry et al; licensee BioMed Central Ltd. This is an Open Access article distributed under the terms of the Creative Commons Attribution License (http://creativecommons.org/licenses/by/2.0), which permits unrestricted use, distribution, and reproduction in any medium, provided the original work is properly cited. 
were recorded using the Structural Index (SI) [4] and the Juvenile Arthritis Foot Disability Index (JAFI) [5]. The progression of the centre of pressure through the left foot, heel, midfoot, forefoot and toe regions was measured using an EMED-X pressure platform. Variables analysed were the average and maximum velocity, velocity at $50 \%$ foot length, and the duration of the centre of pressure. Mean differences between groups and 95\% confidence intervals $(\mathrm{CI})$ were calculated using the $t$-distribution.

\section{Results}

In the JIA group, participants exhibited mild-to-moderate levels of foot impairments, and mild levels of forefoot deformities. No significant differences were observed between group means for all CoP variables (table 1). A trend towards a slower $\mathrm{VCoP}_{\text {ave }}$ at the midfoot in the patients with JIA was observed.

\section{Conclusions}

Foot impairment and deformity scores may represent residual disease impairments that do not appear to profoundly affect foot function. The low levels of forefoot deformity in the JIA group may explain the lack of compensatory off-loading strategies observed. Sub-classification of patients by locality of symptoms in future studies may be useful to determine the clinical utility of centre-of-pressure analysis in this patient population.

\section{Author details}

'School of Health and Life Sciences, Glasgow Caledonian University, Glasgow, Lanarkshire, G4 OBA, UK. 'University of Western Sydney, Sydney, NSW, Locked Bag 1797, Australia. ${ }^{3}$ University of Glasgow, Glasgow, Lanarkshire, G12 8QQ, UK.

Published: 10 April 2012

\section{References}

1. Brostom E, Haglund-Akerlind Y, Hagelberg S, Cresswell AG: Gait in children with juvenile chronic arthritis. Scand J Rheumatol 2002, 31:317-23.

2. Dhanendran M, Hutton W, Klenerman L, Witemeyer S, Ansell B: Foot function in JCA. Rheumatol Rehabil 1980, 19:20-24.

3. Semple R, Turner DE, Helliwell PS, Woodburn J: Regionalised centre of pressure analysis in patients with rheumatoid arthritis. Clinical Biomechanics 2007, 22:127-9.

4. Platto MJ, O'Connell PG, Hicks JE, Gerber LH: The relationship of pain and deformity of the rheumatoid foot to gait and an index of functional ambulation. J Rheumatol 1991, 18:38-43.

5. Andre M, Hagelberg $S$, Stenstrom $\mathrm{CH}$ : The juvenile arthritis foot disability index: development and evaluation of measurement properties. $J$ Rheumatol 2004, 31:2488-93.

doi:10.1186/1757-1146-5-S1-015

Cite this article as: Hendry et al:: Preliminary study of regionalised centre-of-pressure analysis in patients with juvenile idiopathic arthritis. Journal of Foot and Ankle Research 2012 5(Suppl 1):015.

\section{Submit your next manuscript to BioMed Central} and take full advantage of:

- Convenient online submission

- Thorough peer review

- No space constraints or color figure charges

- Immediate publication on acceptance

- Inclusion in PubMed, CAS, Scopus and Google Scholar

- Research which is freely available for redistribution

Submit your manuscript at www.biomedcentral.com/submit 